\title{
Contributions
}

John M. Nunley*, Adam Pugh, Nicholas Romero and R. Alan Seals

\section{Racial Discrimination in the Labor Market for Recent College Graduates: Evidence from a Field Experiment}

\begin{abstract}
We present experimental evidence from a correspondence test of racial discrimination in the labor market for recent college graduates. We find strong evidence of differential treatment by race: black applicants receive approximately $14 \%$ fewer interview requests than their otherwise identical white counterparts. The racial gap in employment opportunities is larger when comparisons are made between job seekers with credentials that proxy for expected productivity and/or match quality. Moreover, the racial discrimination detected is driven by greater discrimination in jobs that require customer interaction. Various tests for the type of discrimination tend to support taste-based discrimination, but we are unable to rule out risk aversion on the part of employers as a possible explanation.
\end{abstract}

Keywords: racial discrimination, employment, productivity, field experiments, correspondence studies

JEL Classification: J23, J24, J71

DOI 10.1515/bejeap-2014-0082

*Corresponding author: John M. Nunley, Department of Economics, University of Wisconsin La Crosse, La Crosse, WI 54601, USA, E-mail: jnunley@uwlax.edu

Adam Pugh, CUNA Mutual Group, Madison, WI 53705, USA, E-mail: adam.pugh@cunamutual.com Nicholas Romero, Department of Economics, University of Pennsylvania, Philadelphia, PA 19104, USA, E-mail: romeron@sas.upenn.edu

R. Alan Seals, Department of Economics, Auburn University, Auburn, AL 36849-5049, USA, E-mail: alan.seals@auburn.edu 


\section{Introduction}

College graduates who entered the labor market during and following the Great Recession experienced high rates of unemployment and underemployment (Abel, Deitz, and Su 2014; Spreen 2013). The labor-market opportunities, while grim for those who completed their degrees during this time period, were worse for blacks. Spreen (2013, table 7) reports unemployment rates for recent college graduates that differ substantially between whites and blacks $(10.6 \%$ for whites and $20.2 \%$ for blacks). Research on the impact of recessions on demographic groups indicates that blacks are disproportionately affected (Hoynes, Miller, and Schaller 2012). ${ }^{1}$ In addition, anecdotal evidence suggests a higher degree of selectivity in hiring on the part of employers during and following the Great Recession. ${ }^{2}$ Given the higher rates of unemployment for blacks relative to whites, it could be the case that employers are selective on the basis of race. We use data from a randomized résumé-audit study to examine racial discrimination in the labor market for college graduates who completed their degrees during the worst employment crisis since the Great Depression.

Discrimination against minority job seekers is a worldwide phenomenon that has been documented in experimental studies of the labor market (Baert et al. 2013; Bertrand and Mullainathan 2004; Booth, Leigh, and Varganova 2012; Carlsson and Rooth 2007; Oreopoulos 2011). The most common experimental design in this literature combines random assignment of perceived productivity and other résumé characteristics with popular first and last/family names that signal race to identify discrimination (e.g., Bertrand and Mullainathan 2004). However, it has proven conceptually difficult to determine whether discrimination is taste-based (i.e., employers have racist preferences) or statistical (i.e., imperfect information causes employers to update their beliefs about future productivity, which may be correlated with race, when confronted with racial-sounding names). Our primary objective is to determine the extent to which racial discrimination can explain the (un)employment gap between white and black college graduates. If discrimination cannot be ruled out, a secondary objective is to determine whether the source of the discrimination is based on tastes or imperfect information.

If the (un)employment differentials between blacks and whites are large early in their careers, employers may have different beliefs about the quality of

1 Hoynes, Miller, and Schaller (2012) show that recessions have disproportionate adverse effects on men, blacks, Hispanics, and less-educated workers relative to other demographic groups. It is also noteworthy that the groups who suffered the most from the Great Recession are the same groups that suffered the most from the recession of the early 1980 s.

2 For an example, see Rampell (2013). 
experience of white and black workers later in their careers, which could complicate an analysis of racial discrimination. As such, we focus on the employment prospects facing recent college graduates in the context of a résumé-audit experiment in which the races of job applicants are signaled with white- and black-sounding names. Approximately 9,400 randomly generated résumés from fictitious, recently graduated job seekers were submitted to online job advertisements from January 2013 through the end of July 2013. All applicants were assigned a college graduation date of May 2010. ${ }^{3}$

The high rates of unemployment and underemployment experienced by people who graduated with a Bachelor's degree in the aftermath of the Great Recession are incorporated into our experiment. In particular, we randomize the timing of gaps in work history and indicate both current and past unemployment spells of different durations. Adequate employment and underemployment are simulated by including two types of work experience: (i) in-field experience that requires a college degree and (ii) out-of-field experience that does not require a college degree. The latter is a proxy for underemployment, i.e., employment in a job that is below one's skill level.

We attempt to further differentiate between statistical and taste-based discrimination, which could arise from perceived differences in the quality of training and/or job-skill match, by assigning approximately half of the applicants traditional business degrees (i.e., accounting, economics, finance, marketing, and management), while the other applicants were assigned degrees from the arts and sciences (i.e., biology, English, history, and psychology). Additionally, we randomly assigned in-field internships to provide another source of experience that is gained before the applicant enters the job market. We then responded to job advertisements exclusively from the business sector (i.e., banking, finance, insurance, management, marketing, and sales) so that we are able to examine how mismatches in qualifications might affect the racial gap in employment opportunities.

Our experimental data indicate that black-named job seekers are approximately $14 \%$ less likely to receive interview requests than applicants with white-sounding names. The racial gap in interview rates increases substantially with credentials that proxy high expected productivity and/or match quality (i.e., business degrees, internship experience, and in-field work experience). Moreover, the baseline estimate for the black-white differential in interview rates is driven primarily by greater discrimination in jobs that require

3 The national unemployment rate was $9.6 \%$ in May 2010, but the unemployment rate among college graduates was only $4.6 \%$ at the time of graduation (http://data.bls.gov/timeseries/ LNS14000000). Spreen (2013) reports that the unemployment rates of college graduates who completed their degrees in the wake of the Great Recession were approximately 13\% in 2010. 
customer interaction. We find no evidence that the uniqueness of the racially identifying names, socioeconomic status, gaps in work history, labor-market conditions, or greater racial discrimination against women are the driving forces behind the estimated black-white differentials in interview rates.

Although we are unable to identify conclusively the channel through which the observed racial gap in interview rates arises, our econometric analysis points toward taste-based discrimination as the most likely explanation. First, we find that the racial gap in employment opportunities widens with attributes that indicate high expected productivity and/or a high degree of match quality between the applicant and the firm. Second, the racial gap in employment opportunities is nonexistent at the lowest skill level (i.e., among applicants with non-business degrees, no internship experience, and out-of-field work experience). These patterns in the data are in line with the hypotheses put forward by Ewens, Tomlin, and Wang (2014) as tests for taste-based discrimination. In addition, estimates based on the methodology proposed by Neumark (2012), which decomposes discrimination into level and variance components, suggest that our baseline model understates the extent of taste-based discrimination. Thus, the bulk of the empirical evidence supports taste-based discrimination as the most likely interpretation for our findings, but we cannot rule out risk aversion on the part of employers as a possible explanation for the racial gap in interview rates.

\section{Empirical and theoretical background}

Earlier studies in the discrimination literature primarily rely on regression analysis of survey data to test for the presence and type of discrimination. For the most part, these studies find lower wages and poorer job opportunities for blacks (Altonji and Blank 1999). Regression-based studies on racial discrimination have been criticized, as the estimates are sensitive to the data set used and choice of control variables (Riach and Rich 2002). The inability to control for unobserved differences between blacks and whites makes it difficult to test reliably for the presence of racial discrimination as well as the channel through which discrimination operates. ${ }^{4}$

4 Charles and Guryan (2008) provide a test of Becker's (1971) model of taste-based discrimination using a variety of different data sets based on surveys, but their purpose is not to determine whether the data support a particular theory but to test certain predictions made by Becker (1971). Fryer, Pager, and Spenkuch (2011) use a longitudinal data set of unemployed workers in New Jersey to examine racial differences in job-finding rates and wage offers. Their findings are supportive of statistical discrimination, in which the firms may learn about worker productivity over time. However, they are unable to rule out other interpretations. 
Experimental design can circumvent many of the estimation problems associated with survey data. Laboratory experiments have successfully isolated particular channels through which discrimination occurs. Ball et al. (2001) find evidence of in-group bias; Glaeser et al. (2000) find that trust and trustworthiness are important determinants of discrimination; and Fershtman and Gneezy (2001) find evidence of statistical discrimination. ${ }^{5}$ However, the ability of researchers to extrapolate the results of laboratory experiments to "real-world" situations has been questioned (Levitt and List 2007). Field experiments provide a useful alternative to laboratory experiments because they take place in naturally occurring environments and, much like laboratory experiments, provide substantial control over the variables of interest. ${ }^{6}$

Two types of field experiments are primarily used to study racial discrimination in the labor market: in-person and correspondence audits. For the in-person audits, white and black "actors" are recruited and trained to navigate the interview process as if they are perfect substitutes. Such studies have been criticized because of the fragility of the estimates to different assumptions regarding unobservables (Heckman 1998; Heckman and Siegelman 1993). In addition, the "actors" in the experiments are aware of the goals of the experiment, which has the potential to influence their behavior and produce misleading results. Correspondence audits, which send résumés instead of actual people to apply for jobs, offer advantages over in-person audits because researchers can make members of particular groups appear identical to employers in every respect other than the variable(s) of interest (e.g., race) via careful matching of applicant characteristics or randomization (Bertrand and Mullainathan 2004; Lahey 2008). ${ }^{7}$ Correspondence studies are void of so-called experimenter effects, as the subjects (i.e., employers) are unaware that they are part of an experiment and the job seekers are fictitious. Because employers are unaware that they are the subjects of an experiment, correspondence tests likely elicit the behavior employers exhibit in actual hiring decisions.

5 Anderson, Fryer, and Holt (2006) provide a review of these studies as well as others that rely on laboratory experiments to study discrimination.

6 Field experiments have been used in many different settings to study discrimination, but researchers have generally focused on three markets: labor markets (Bertrand and Mullainathan 2004; Carlsson and Rooth 2007; Lahey 2008; Neumark et al. 1996; Oreopoulos 2011); housing markets (Ahmed and Hammarstedt 2008; Bosch, Carnero, and Farre 2010; Ewens, Tomlin, and Wang 2014; Yinger 1986); and product markets (Ayres and Siegleman 1995; Doleac and Stein 2013; List 2004; Nunley, Owens, and Stephen Howard 2011).

7 There is a lengthy history of correspondence tests in the literature. Riach and Rich (2002) provide an overview of field experiments aimed at testing for discrimination in various market settings. 
The most relevant study for our purpose is Bertrand and Mullainathan (2004), who examine racial discrimination in the U.S. with a correspondence methodology that incorporates racially distinct names to signal race to prospective employers. They find that black applicants receive about 50\% fewer callbacks/interviews than their white counterparts. As in most studies of discrimination, Bertrand and Mullainathan (2004) relate their findings to existing theories. Neither taste-based nor statistical discrimination models convincingly explain their results. They argue that lexicographic search by employers, in which employers examine an applicant's name and look no further, could explain the lower return to credentials that are detected for black applicants.

Our study differs from Bertrand and Mullainathan (2004) in several ways. First, we focus on recent college graduates who entered the labor market during the worst employment crisis since the Great Depression. It is important to understand how discrimination might inhibit skilled workers (i.e., the collegeeducated) early in their careers, as such discrimination could have important policy implications. Second, we create fictitious job seekers with short work histories, as the use of applicants with lengthy work histories complicates tests for the type of discrimination. A sample of job seekers with short work histories and randomly assigned "hard" skills (i.e., in-field and internship experience) provides a cleaner test for the type of racial discrimination recently graduated job seekers might encounter. Third, we use a recent econometric technique (i.e., Neumark 2012) and testable hypotheses posited by Ewens, Tomlin, and Wang (2014) to aid in sorting out the explanation for the observed black-white differentials. Fourth, we test whether there is greater (or less) discrimination in jobs that require substantial interaction with customers as a means to examine a particular aspect of Becker's (1971) theory. Fifth, we test whether the extent of racial discrimination is greater (or smaller) in relatively "tight" and "loose" labor markets. Sixth, Bertrand and Mullainathan (2004) focus on administrative- and clerical-type jobs, which results in a focus on racial differences between women rather than racial discrimination against men and women. We apply to a wide range of jobs across six different business categories, which allows us to study racial discrimination within and between sexes across a wider range of occupations.

Neumark (2012) contends that correspondence studies are likely to address complications associated with mean differences in unobservables between blacks and whites. However, both in-person and correspondence audits share the common limitation that the perceived variance of unobserved characteristics may differ between members of particular groups. Unequal variances of the unobserved determinants of the outcome variable can lead to spurious evidence in favor or against discrimination (Heckman 1998; Heckman and Siegelman 
1993). As a result, differentiating between theories based on tastes (Becker 1971) or imperfect information (Aigner and Cain 1977; Arrow 1973; Cornell and Welch 1996; Lundberg and Startz 1983; Phelps 1972) is equally difficult in both the inperson and correspondence audits. However, correspondence studies are likely to identify what the law considers discrimination, which is effectively the sum of taste-based and statistical discrimination (Neumark 2012). We use two different approaches to test for different types of discrimination: one used by Bertrand and Mullainathan (2004) and Lahey (2009), which relies on race-credential interactions, and another advanced by Neumark (2012), which decomposes discrimination into "level" and "variance" components. ${ }^{8}$

Ewens, Tomlin, and Wang (2014) posit four testable hypotheses for tastebased discrimination in the context of an output market. We believe three of these hypotheses are testable, albeit imperfectly, with our data. Hypotheses 2A and $3 \mathrm{~A}$ are of particular interest:

Hypothesis 2A: On average, the response gap between white and black applicants when a positive signal is sent is larger than the response gap between white and black applicants when a negative signal is sent. (p. 125)

Hypothesis 3A: On average, negative information will unambiguously narrow the racial gap observed in the no-signal base case, but positive information will unambiguously widen the racial gap observed in the base case. (p. 125)

While the "no-signal" base case is not possible in a résumé-audit study, which is an advantage of Ewens, Tomlin, and Wang's (2014) reliance on rental-housing markets, we include substantial variation in the perceived productivity characteristics of the résumés, which allows us to use the framework developed by Ewens, Tomlin, and Wang (2014) to help identify the channel through which racial discrimination operates. In particular, we investigate Hypothesis 2A by testing whether the racial gap in employment opportunities increases when comparisons are made between black and white job seekers with positive attributes (i.e., business degrees, internship experience, and in-field work experience). Moreover, we investigate Hypothesis 3A by comparing black and white applicants with the lowest skill level (i.e., those with non-business degrees, no internship experience, and out-of-field work experience).

8 The methodology proposed by Neumark (2012) is discussed in more detail in Section 4.2. It is sufficient, at this point, to note that the level component is the structural parameter, which measures taste-based discrimination, and the variance component measures statistical discrimination in the context of Aigner and Cain (1977). 


\section{Experimental design}

We submitted approximately 9,400 randomly created résumés to online advertisements for job openings across multiple job categories in seven large cities across the U.S. ${ }^{9}$ The job categories are banking, finance, management, marketing, insurance, and sales, and the cities are Atlanta, GA, Baltimore, MD, Boston, MA, Dallas, TX, Los Angeles, CA, Minneapolis, MN, and Portland, OR. The submission of résumés took place from January 2013 through the end of July 2013.

For each job advertisement, we submitted four résumés. The four résumés are randomly assigned a number of different characteristics, which are generated using the computer program developed by Lahey and Beasley (2009). We chose eight applicant names for our study. Four of the names are distinctively female, while the remaining four names are distinctively male. In both the male and female categories, two of the names are "distinctively white," while the other two names are "distinctively black." The distinctively white female names are Claire Kruger and Amy Rasmussen, and the distinctively black female names are Ebony Booker and Aaliyah Jackson. The distinctively white male names are Cody Baker and Jake Kelly, and the distinctively black male names are DeShawn Jefferson and DeAndre Washington. ${ }^{10}$ Each of the first and family names ranks at or near the top of the "whitest" and "blackest" names in the U.S. We use the racial distinctiveness of the applicants' names to signal race to prospective employers. ${ }^{11}$

Our fictitious applicants graduated with a Bachelor's degree in May 2010. We randomly assign each applicant a name (one of the eight listed above), a street address, a university where their Bachelor's degree was completed,

9 We applied to job openings through two well-known online job search websites. Per our Institutional Review Board (IRB) agreements, we are unable to disclose the names of these websites.

10 Within a four-applicant pool, each of the eight names is randomly assigned with equal probability. Once a name has been assigned, the name is excluded from being assigned to other job seekers in the four-applicant pool. Thus, it is possible for all four names to be distinctively white or black, but the names would differ by gender. In addition, it is possible for all four names to be male or female, but the names would differ by race. Collectively, these scenarios occur a total of eight times in our data. Thus, less than $1 \%$ of the observations are affected by the homogeneity of race or sex within a four-applicant pool. Because there are eight names, the means for the dummy variables representing each name should be around $12.5 \%$, which is the case in our data. Furthermore, we test, similar to Table 1, for covariate balance among each of the names, finding that the résumé credentials are distributed similarly to each name.

11 Racially or ethnically distinct names are commonly used in studies like ours. Examples include Ahmed and Hammarstedt (2008), Bertrand and Mullainathan (2004), Bosch, Carnero, and Farre (2010), Carlsson and Rooth (2007), and Nunley, Owens, and Stephen Howard (2011). The reliability of the racially distinct names as signals for race is discussed in Section 4.2. 
academic major, (un)employment statuses, ${ }^{12}$ whether they report their grade point average (GPA) on their résumé, whether the applicant completed their Bachelor's degree with an Honor's distinction, whether the applicant has work experience specific to the job category for which they are applying, and whether the applicant worked as an intern while completing their Bachelor's degree. Each of these randomized résumé characteristics is coded as zero-one indicator variables. ${ }^{13}$

While much of the experimental design is produced via randomization, there are some features of the experiment that are held constant. First, we assigned a Bachelor's degree to each of our fictitious résumés. The assignment of only Bachelor's degrees is driven by our interest in the labor-market opportunities facing college graduates, particularly those who graduated during the worst employment crisis since the Great Depression. Second, we only applied to jobs in business-related fields: banking, finance, insurance, marketing, management, and sales. We submit applications to job categories which are associated with business degrees/experience in order to examine mismatch in qualifications between black and white applicants. Third, we applied to jobs that met the following criteria: (i) no certificate or specific training was required for the job; (ii) the prospective employer did not require a detailed application be submitted; (iii) and the prospective employer only required the submission of a résumé to be considered for the job. The decision to apply for jobs that did not require detailed application procedures is driven by the need to (a) avoid introducing unwanted variation into the experimental design and (b) maximize the number of résumés submitted at the lowest possible cost. The only decision that was made on our part that could affect the estimates is the selection of the jobs to which applications were submitted. That is, there may be unobserved heterogeneity at the job level. Because we sent four résumés to each job opening, this potential source of bias is mitigated by the inclusion of job-advertisement dummy variables, which holds constant unobservables specific to all four

12 Eriksson and Rooth (2014), Kroft, Lange, and Notowidigdo (2013), and Nunley et al. (2014a) examine how different length unemployment spells affect job opportunities using the correspondence-audit methodology.

13 Because of the extensive detail associated with each of the résumé characteristics mentioned in this paragraph, we relegate this information to Online Appendix A1.1, which provides the details on each of the résumé characteristics. However, we use a number of these résumé characteristics to conduct indirect tests that shed light on which theory of discrimination best fits the data. When we use a particular résumé attribute, we discuss the important aspects of the attribute at that point in the paper. Online Appendix A1.2 provides some examples of the résumés that were submitted, and Online Appendix A1.3 provides information on the application process. 
résumés. In addition, we cluster standard errors at the job-advertisement level, which follows other correspondence studies (e.g., Lahey 2008; Neumark 2012).

Because we use randomization to examine the effects of race on employment prospects, it is important to ensure that our randomization process distributes the résumé attributes to black and white applicants in similar ways. Table 1 presents the means for a subset of the résumé characteristics for all applicants (column 1), black applicants (column 2), and white applicants (column 3). ${ }^{14}$ In column 4 , the $p$-values for the difference-in-means tests between black and white applicants for each résumé attribute are presented. ${ }^{15}$ It is apparent from the difference-in-means tests that black and white applicants are assigned each of the résumé characteristics similarly, as none of the estimated differentials is statistically different from zero. In addition, the sample means for the résumé characteristics overall and by race are consistent with the probabilities chosen for the random assignment of the résumé credentials (see Online Appendix A1.1 for information on these probabilities).

We proxy employment opportunities with interview requests from prospective employers. A response is treated as an interview request when an employer calls or e-mails to schedule an interview or requests to speak in more detail about the opening with the applicant. Our measure of employment prospects, i.e., the interview rate, is similar to the measures commonly used in other correspondence studies (e.g., Bertrand and Mullainathan 2004). It is possible for us to consider "positive" responses (e.g., Lahey 2008), but the estimates are not sensitive to this alternative coding of the dependent variable because the majority of "callbacks" fall into the interview-request category. ${ }^{16}$ As a result, we omit these results from the paper.

14 We omit a few of the résumé credentials from Table 1, as they are not central to our empirical models. These remaining attributes include the university where the applicant graduated from, whether the applicant reports their GPA on their résumé, whether the applicants completed their degree with an Honor's distinction, and the type of job the applicant had while they were completing their degree. However, the means of these characteristics are consistent with the probabilities assigned to such attributes, and the difference-in-means tests between black and white applicants are not statistically different from zero. These estimates are available upon request.

15 The differences-in-means tests are conducted by estimating a linear regression of the résumé credential on a constant and a dummy variable that equals one when an applicant is assigned a black-sounding name and zero when an applicant is assigned a white-sounding name.

16 There were five types of "callbacks" for which coding the dependent variable is unclear. First, we received six callbacks from firms that asked if the applicant was interested in other positions. Second, we received one callback from a firm that requested information from the applicant regarding salary requirements. Third, we received two callbacks from firms that asked whether the applicant was interested in full- or part-time work. Fourth, we received eight callbacks from firms that asked if the applicants had a location preference. Fifth, we received 108 callbacks from firms requesting applicants to complete another step in the interview process (i.e., filling out a detailed 
Table 1: Covariate balance between black and white applicants.

\begin{tabular}{lrrrr}
\hline Covariate & $\begin{array}{r}\text { All } \\
\text { applicants }\end{array}$ & $\begin{array}{r}\text { Black } \\
\text { applicants }\end{array}$ & $\begin{array}{r}\text { White } \\
\text { applicants }\end{array}$ & $\begin{array}{r}\boldsymbol{p} \text {-Values for } \\
\text { black-white } \\
\text { differences }\end{array}$ \\
\hline Female & 0.499 & 0.494 & 0.504 & 0.331 \\
High socioeconomic status & 0.499 & 0.498 & 0.501 & 0.804 \\
No gap in work history & 0.254 & 0.254 & 0.256 & 0.782 \\
3-Month front-end gap & 0.125 & 0.120 & 0.129 & 0.180 \\
6-Month front-end gap & 0.121 & 0.121 & 0.121 & 0.918 \\
12-Month front-end gap & 0.125 & 0.128 & 0.122 & 0.383 \\
3-Month back end gap & 0.124 & 0.124 & 0.124 & 0.949 \\
6-Month back end gap & 0.123 & 0.124 & 0.122 & 0.756 \\
12-Month back end gap & 0.127 & 0.129 & 0.125 & 0.493 \\
Business degree & 0.552 & 0.551 & 0.553 & 0.907 \\
Internship experience & 0.248 & 0.248 & 0.249 & 0.866 \\
In-field work experience & 0.501 & 0.498 & 0.502 & 0.696 \\
\hline
\end{tabular}

Notes: The covariates listed are zero-one dummy variables. "Female" equals one when an applicant is assigned a female name; "High socioeconomic status" equals one when an applicant is assigned a high-socioeconomic-status street address; "No gap in work history" equals one when an applicant is assigned no gap in their work history; "3-Month front-end gap" equals one when an applicant is assigned a 3-month unemployment spell immediately after graduation; "6-Month front-end gap" equals one when an applicant is assigned a 6-month unemployment spell immediately after graduation; "12-Month front-end gap” equals one when an applicant is assigned a 12-month unemployment spell immediately after graduation; "3-Month back end gap" equals one when an applicant is assigned a 3-month unemployment spell at the time of application; "6-Month back end gap" equals one when an applicant is assigned a 6-month unemployment spell at the time of application; "12-Month back end gap" equals one when an applicant is assigned a 12-month unemployment spell at the time of application; "Business degree" equals one when applicant is assigned a business degree; "Internship experience" equals one when an applicant is assigned internship experience while completing their degree; and "In-field work experience" equals one when an applicant is assigned in-field work experience following graduation. Each of these résumé characteristics as well as those not listed in the table is described in Online Appendix A1.1.

application). However, when this happened, all four applicants that applied to the job received the same e-mail or phone call, suggesting that the response from the prospective employers might have been automated. Alternatively, these situations might indicate no discrimination on the part of these firms. However, the inclusion of job-specific dummy variables removes the influence of these types of callbacks. In total, there were 125 callbacks for which coding of the dependent variable is unclear. The estimates presented in Section 4 treat these callbacks as interview requests. However, we checked the robustness of our estimates to these callbacks by treating them as non-interview requests and by including observation-specific dummy variables, finding similar estimated blackwhite differentials. 
Table 2: Average interview rates.

\begin{tabular}{|c|c|c|c|c|}
\hline & All (1) & White (2) & Black (3) & Difference in means (4) \\
\hline Overall & 0.166 & 0.180 & 0.152 & $-0.028^{\star \star \star}$ \\
\hline \multicolumn{5}{|l|}{ By city } \\
\hline Atlanta & 0.131 & 0.148 & 0.114 & $-0.034^{\star \star}$ \\
\hline Baltimore & 0.257 & 0.254 & 0.248 & -0.006 \\
\hline Boston & 0.130 & 0.144 & 0.116 & -0.028 \\
\hline Dallas & 0.180 & 0.199 & 0.161 & $-0.038^{\star \star}$ \\
\hline Los Angeles & 0.138 & 0.157 & 0.119 & $-0.037^{\star \star}$ \\
\hline Minneapolis & 0.181 & 0.200 & 0.163 & $-0.037^{\star \star}$ \\
\hline Portland & 0.160 & 0.169 & 0.152 & -0.017 \\
\hline \multicolumn{5}{|l|}{ By job category } \\
\hline Banking & 0.090 & 0.112 & 0.070 & $-0.042^{\star \star}$ \\
\hline Finance & 0.102 & 0.110 & 0.094 & -0.015 \\
\hline Insurance & 0.243 & 0.276 & 0.210 & $-0.065^{\star \star \star}$ \\
\hline Management & 0.103 & 0.107 & 0.099 & -0.007 \\
\hline Marketing & 0.214 & 0.218 & 0.209 & -0.008 \\
\hline Sales & 0.215 & 0.233 & 0.195 & $-0.038^{\star \star}$ \\
\hline
\end{tabular}

Notes: There are 1,385 observations from Atlanta; 1,146 observations from Baltimore; 1,339 observations from Boston; 1,415 observations from Dallas; 1,375 observations from Los Angeles; 1,386 observations from Minneapolis; and 1,377 observations from Portland. For the job categories, there are 929 observations from banking; 1,636 observations from finance; 1,067 observations from management; 1,046 observations from marketing; and 2,326 observations from sales. $* \star$ and $* \star *$ indicate statistical significance at the $5 \%$ and $1 \%$ levels, respectively.

Table 2 presents summary statistics for the interview rates overall and by race. The baseline interview rate in the sample is slightly over $16 \%$, with white applicants having a higher-than-average interview rate and black applicants having a lower-than-average interview rate. The unconditional difference in the interview rates between black and white applicants is approximately 2.7 percentage points, which is statistically significant at the $1 \%$ level. The interview rates vary across cities. Atlanta and Boston have the lowest overall interview rates at about $13 \%$, while Baltimore has the highest interview rate at about $25 \%$. When the city-specific interview rates are separated by race, we observe lower interview rates for blacks relative to whites across all cities. The majority of the unconditional city-specific differences in the interview rates between black and white applicants are statistically significant at conventional levels. There is also variation in the interview rates by job category. Insurance, marketing, and sales have the highest interview rates, which are each in excess of $20 \%$. Banking, finance, and management have the lowest interview rates, which are around 
$10 \%$ or slightly less. The interview rates for black applicants are lower, in some cases substantially, than their white counterparts for each of the job categories. The unconditional differences in the interview rates between black and white applicants are statistically significant at conventional levels for most of the job categories. While the racial differences in interview rates presented in Table 2 are suggestive of differential treatment by race, a formal analysis is required to determine whether these differences reflect discrimination and, if so, the type of discrimination observed.

\section{Results}

\subsection{Baseline estimates}

Our baseline regression model is

$$
\text { interview }_{\text {imcfj }}=\beta_{0}+\beta_{1} \text { black }_{i}+\gamma \mathbf{X}_{i}+\phi_{m}+\phi_{c}+\phi_{f}+\phi_{j}+u_{i m c f j}
$$

The subscripts $i, m, c, f$, and $j$ index applicants, months, cities, job categories, and job advertisements, respectively. The variable interview is a zero-one indicator variable that equals one when an applicant receives a request for an interview and zero otherwise; black is a zero-one indicator variable that equals one when the name of the applicant is distinctively black and zero when the name of the applicant is distinctively white; $\mathbf{X}$ is a vector of résumé-specific controls, which includes all of the résumé characteristics that are randomly assigned to applicants; ${ }^{17} \phi_{m}, \phi_{c}, \phi_{f}$, and $\phi_{j}$ represent sets of dummy variables for the month, city, job category, and job advertisement, respectively; $u$ represents other factors that are not held constant that affect interview rates; and $\beta_{0}, \beta_{1}$, and $\gamma$ are parameters. We are primarily interested in the parameter $\beta_{1}$, which gives the average difference in the interview rate between black and white applicants.

The use of randomization ensures that the race identifier (black) in eq. [1] is orthogonal to the error term $(u)$, allowing us to interpret the parameter attached to the race identifier as the causal difference in the interview rate between black and white applicants. However, the estimate for $\beta_{1}$ does not provide an explicit test for the type of discrimination observed. As pointed out by Heckman and Siegelman (1993), Heckman (1998), and Neumark (2012), mean differences in

17 The résumé characteristics are introduced in Section 3, but these attributes are discussed indepth in the online appendix. The online appendix is available at the following webpage: http://johnnunley.org/race_appendix_jan_2015.pdf 
unobservables and differences in the variances of unobservables between blacks and whites confound attempts to parse taste-based discrimination from statistical discrimination. Neumark (2012) contends that correspondence studies, like the one that we use, are likely to circumvent the critique regarding mean differences in unobservables between groups, given that such studies are better at controlling what employers observe. ${ }^{18}$ However, Neumark (2012) argues that the correspondence methodology (as well as in-person audits) does not circumvent the critique regarding the possibility that the variances of unobservables between blacks and whites differ. As a result, the estimates presented in this section likely capture what the law considers discrimination, which is effectively the sum of taste-based and statistical discrimination. We investigate whether the racial discrimination detected is rooted in preferences or the result of an information problem in Section 4.3.

Table 3 presents estimates for the parameter $\beta_{1}$ from eq. [1]. The columns in Table 3 differ based on the explanatory variables included in the regression

Table 3: Race and job opportunities.

\begin{tabular}{|c|c|c|c|c|c|c|}
\hline & (1) & (2) & (3) & (4) & (5) & (6) \\
\hline Black & $\begin{array}{l}-0.028^{\star \star *} \\
(0.007)\end{array}$ & $\begin{array}{l}-0.027^{* * *} \\
(0.007)\end{array}$ & $\begin{array}{l}-0.027^{\star * \star} \\
(0.007)\end{array}$ & $\begin{array}{l}-0.027^{\star \star \star} \\
(0.007)\end{array}$ & $\begin{array}{l}-0.026^{* * *} \\
(0.007)\end{array}$ & $\begin{array}{l}-0.022^{\star \star \star} \\
(0.006)\end{array}$ \\
\hline \multicolumn{7}{|l|}{ Controls: } \\
\hline Résumé & No & Yes & Yes & Yes & Yes & Yes \\
\hline Month & No & No & Yes & Yes & Yes & Yes \\
\hline City & No & No & No & Yes & Yes & Yes \\
\hline Category & No & No & No & No & Yes & Yes \\
\hline Advertisement & No & No & No & No & No & Yes \\
\hline$R^{2}$ & 0.002 & 0.008 & 0.010 & 0.018 & 0.044 & 0.724 \\
\hline Adjusted $R^{2}$ & 0.001 & 0.005 & 0.006 & 0.014 & 0.039 & 0.630 \\
\hline Observations & 9396 & 9396 & 9396 & 9396 & 9396 & 9396 \\
\hline
\end{tabular}

Notes: Estimates are marginal effects from linear probability models. Standard errors clustered at the job-advertisement level are in parentheses. ${ }^{\star \star \star}$ indicates statistical significance at the $1 \%$ level. "Résumé" represents controls for the randomized résumé characteristics other than race; "Month" represents month-of-application dummy variables; "City" represents city-of-application dummy variables; "Category" represents job-category (i.e., banking, finance, management, marketing, insurance, and sales) dummy variables; and "Advertisement" represents dummy variables for the job for which applications were submitted. The estimates presented are based on eq. [1].

18 For the purposes of clarity, we note that it is impossible to control all of the résumés that an employer observes. However, we are able to control what employers observe regarding the four résumés submitted for consideration. 
models. Column (1) includes no controls; column (2) includes controls for the randomly assigned résumé characteristics $(\mathbf{X})$; column (3) adds the set of monthof-application dummy variables $\left(\phi_{m}\right)$; column (4) adds the city-of-application dummy variables $\left(\phi_{c}\right)$; column (5) adds the job-category/industry dummy variables $\left(\phi_{f}\right)$; and column (6) adds the job-advertisement dummy variables $\left(\phi_{j}\right)$. The estimated differences in the interview rates between black and white applicants are stable as control variables are successively added, although there is a slight decline in the estimated racial gap when the job-advertisement dummy variables are included.

For the comparisons between black and white applicants, the estimated black-white differentials in interview rates range from -0.022 to -0.028 percentage points. The most reliable estimate is likely the one shown in column (6), which includes the complete set of control variables (i.e., $\mathbf{X}, \phi_{m}, \phi_{c}, \phi_{f}, \phi_{j}$ from eq. [1]). In that specification, black applicants have a 2.2 percentage point lower interview rate than otherwise identical white applicants. Because the average interview rate in the sample is about $16 \%$, the interview rate for black applicants is approximately $14 \%$ lower than that for white applicants. Each of the estimated differentials in Table 3 is statistically significant at the $1 \%$ level.

\subsection{Sensitivity checks}

Our first sensitivity check examines whether the interview rates differ by race and sex. ${ }^{19}$ Table 4 presents these estimates. Columns (1) and (2) provide within-

Table 4: Race-sex interactions and interview rates.

\begin{tabular}{ccccc}
\hline & $\begin{array}{r}\text { Black men } \\
\text { versus white } \\
\text { men (1) }\end{array}$ & $\begin{array}{r}\text { Black women } \\
\text { versus white } \\
\text { women (2) }\end{array}$ & $\begin{array}{r}\text { Black men } \\
\text { versus white } \\
\text { women (3) }\end{array}$ & $\begin{array}{r}\text { Black women } \\
\text { versus white } \\
\text { men (4) }\end{array}$ \\
\hline $\begin{array}{c}-0.019^{\star \star} \\
\text { Difference in the } \\
\text { interview rate }\end{array}$ & $\begin{array}{c}-0.025^{\star \star \star} \\
(0.008)\end{array}$ & $\begin{array}{l}-0.009) \\
(0.009)\end{array}$ & $\begin{array}{c}-0.016^{\star \star} \\
(0.008)\end{array}$ \\
\hline
\end{tabular}

Notes: Estimates are marginal effects from linear probability models. Standard errors clustered at the job-advertisement level are in parentheses. ${ }^{* *}$ and ${ }^{* * *}$ indicate statistical significance at the $5 \%$ and $1 \%$ levels, respectively. The full sample of 9,396 observations is used for each regression model and the full set of control variables from eq. [1] is included. The details on how the estimates presented are produced are provided in online Appendix A2.1.

19 We also tested for different interview rates between men and women, finding no economically or statistically significant difference in their interview rates (see Online Appendix Table A1). 
sex comparisons, and columns (3) and (4) provide between-sex comparisons. Each of the estimate interview differentials is negative and statistically significant at conventional levels. Ultimately, these tests reveal that black men and black women experience similar treatment in the labor market in terms of interview rates, as both have lower interview rates than white men and white women. The magnitudes of estimated differences vary somewhat, but statistical tests indicate that the black-white male differential is not statistically different from the black-white female differential. Given that there is no statistical evidence of race-sex differences in interview rates, the remainder of sensitivity checks focuses on racial differences in lieu of race-sex differences. ${ }^{20}$

Although the use of racially distinct names as a signal of race is not a perfect substitute for the random assignment of race, it is perhaps the best approach advanced in the literature in recent years. However, the use of racially distinct names introduces potential confounds. For example, Charles and Guryan (2011) argue that employers could view distinctively black names as unique or odd, and discriminate based on those perceptions. Such differential treatment would be discrimination, but it would not be racial in nature.

We use the Social Security Administration's data on baby names to examine the popularity of our first names for the black and white applicants. While the rankings change from year to year, we examine the rankings (in terms of popularity) of the chosen first names to obtain a sense of how common or uncommon the first names are for babies born in the late 1980s and early 1990s, which is approximately when our applicants would have been born. For the white names, Amy is ranked about 50th; Claire is ranked about 150th; Cody is ranked about 40th; and Jake is ranked about 140th. For the black names, Ebony is ranked about 160th; Aaliyah is ranked about 200th; DeAndre is ranked about 250th; and DeShawn is ranked about 450th. While the distinctively black names are less frequent, it is important to point that these rankings are based on popular male and female names overall, not by race. In addition, data on last/ family names from the U.S. Census suggest that the "white" and "black" last/ family names chosen are likely to reinforce the racial distinctiveness of the first names.

A second criticism of using racially distinct names is that they may signal socioeconomic status instead of race. We incorporate socioeconomic status into

20 It is also important to point out that the applicants with particular black names are discriminated against similarly. That is, the interview rates for DeShawn, DeAndre, Ebony, and Aaliyah are not statistically different from each other, and they are lower by similar magnitude when separately compared to each of the white names (i.e., Amy, Claire, Cody, and Jake). 
our experimental design by randomly assigning street addresses in neighborhoods with high and low house prices. The indicator for high socioeconomic status is a street address with house prices of $\$ 750,000$ or more, while the indicator for low socioeconomic status is a street address with house prices that are $\$ 100,000$ or less.

While there is no clear-cut way to deflect concerns that the racially distinct names reflect race in lieu of uniqueness or socioeconomic status, we use two approaches to address these concerns. First, we examine a subset of the full sample that excludes the most popular and least popular first names from the sample. The names with the highest rankings are Amy and Cody, and the name with the lowest ranking is DeShawn. Excluding observations from applicants with these names effectively results in a sample of applicants with names that have similar frequency in the population. We address the socioeconomic-status concern by estimating racial differences in interview rates for applicants with street addresses in high- and low-socioeconomic-status neighborhoods, which is similar to the strategy used by Bertrand and Mullainathan (2004).

The sensitivity checks focused on the uniqueness and socioeconomic status of the racially distinct names are presented in Table 5. Column (1) shows the estimated difference in the interview rate between black and white applicants with common names; columns (2) and (3) present the estimated differences in the interview rates between black and white applicants with low-socioeconomicstatus addresses; and columns (4) and (5) present the estimated differences in the interview rates between black and white applicants with high-socioeconomic-status addresses. Columns (2) and (3) and columns (4) and (5) differ

Table 5: Race, uniqueness, and socioeconomic status.

\begin{tabular}{|c|c|c|c|c|c|}
\hline & \multirow{2}{*}{$\begin{array}{r}\text { Common } \\
\text { names } \\
(1)\end{array}$} & \multicolumn{2}{|c|}{ Low socioeconomic status } & \multicolumn{2}{|c|}{ High socioeconomic status } \\
\hline & & $\begin{array}{r}\text { Full } \\
\text { sample (2) }\end{array}$ & $\begin{array}{r}\text { Common } \\
\text { names (3) }\end{array}$ & $\begin{array}{r}\text { Full } \\
\text { sample (4) }\end{array}$ & $\begin{array}{r}\text { Common } \\
\text { names (5) }\end{array}$ \\
\hline Black & $\begin{array}{l}-0.027^{\star \star \star} \\
(0.009)\end{array}$ & $\begin{array}{l}-0.022^{\star \star} \\
(0.009)\end{array}$ & $\begin{array}{l}-0.029^{\star \star} \\
(0.014)\end{array}$ & $\begin{array}{l}-0.021^{\star \star} \\
(0.008)\end{array}$ & $\begin{array}{l}-0.023^{\star} \\
(0.014)\end{array}$ \\
\hline Observations & 5,811 & 9,396 & 5,811 & 9,396 & 5,811 \\
\hline
\end{tabular}

Notes: Estimates are marginal effects from linear probability models. Standard errors clustered at the job-advertisement level are in parentheses. *, **, and ${ }^{* \star *}$ indicate statistical significance at the $10 \%, 5 \%$ and $1 \%$ levels, respectively. The samples used in columns (1), (3), and (5) include only observations from applicants with "common" names, while the full sample is used to produce the estimates in columns (2) and (4). The full set of control variables from eq. [1] is included in each regression model. The details on how the estimates presented are produced are provided in online Appendix A2.2. 
based on the sample that is used, as columns (2) and (4) use the full sample and columns (3) and (5) use the subsample based on applicants with common names. In column (1), the estimates indicate that black applicants have a 2.7 percentage point lower interview rate than otherwise identical white applicants, and this estimated differential is statistically significant at the $1 \%$ level. The estimates for applicants with low-socioeconomic-status street addresses range from -0.022 to -0.029 , which varies depending on the sample used. Each of these estimates is statistically significant at the 5\% level. The estimates for applicants with high-socioeconomic-status street addresses range from -0.021 to -0.023 . The former estimate is statistically significant at the $5 \%$ level, while the latter estimate is statistically significant at the $10 \%$ level. The coefficient estimate for the interaction term, which tests whether the estimated black-white differential for applicants with high-socioeconomic-status addresses and that for applicants with low-socioeconomic-status addresses are statistically different from one another, is omitted from Table 5, but the estimate is small economically and not statistically different from zero. To the extent the subset of names analyzed are truly common, which is supported by name data, and the measure that we use indicates socioeconomic status reliably, our results in Table 3 do not appear to reflect differential treatment based on the uniqueness of the applicant's first and last names or socioeconomic status, which increases the likelihood that our estimates reflect differential treatment by race.

Because we randomized gaps in the work histories of applicants, it is possible that the black-white differentials detected in Table 3 could be driven by lower interview rates for blacks with unemployment spells. To investigate this possibility, we estimate a variant of eq. [1] that includes interactions between the race identifier and unemployment-spell identifiers. The estimates presented in Table 6 test whether unemployment spells affect blacks more or less adversely

Table 6: Race, unemployment spells, and job opportunities.

\begin{tabular}{|c|c|c|c|c|c|c|}
\hline & $\begin{array}{r}\text { unemp }^{3 m o} \\
\text { relative to } \\
\text { employed } \\
(1)\end{array}$ & $\begin{array}{r}\text { unemp }^{6 \mathrm{mo}} \\
\text { relative to } \\
\text { employed } \\
(2)\end{array}$ & $\begin{array}{r}\text { unemp }^{12 \mathrm{mo}} \\
\text { relative to } \\
\text { employed } \\
(3)\end{array}$ & $\begin{array}{r}\text { unemp }^{6 \mathrm{mo}} \\
\text { relative to } \\
\text { unemp } \\
\text { (4) }\end{array}$ & $\begin{array}{r}\text { unemp }^{12 \mathrm{mo}} \\
\text { relative to } \\
\text { unemp } \\
\text { (5) }\end{array}$ & $\begin{array}{r}\text { unemp }^{12 \mathrm{mo}} \\
\text { relative to } \\
\text { unemp }^{6 \mathrm{mo}} \\
(6)\end{array}$ \\
\hline Black & $\begin{array}{l}-0.008 \\
(0.019)\end{array}$ & $\begin{array}{l}-0.011 \\
(0.021)\end{array}$ & $\begin{array}{l}-0.002 \\
(0.020)\end{array}$ & $\begin{array}{r}0.019 \\
(0.026)\end{array}$ & $\begin{array}{r}0.006 \\
(0.024)\end{array}$ & $\begin{array}{l}-0.013 \\
(0.026)\end{array}$ \\
\hline
\end{tabular}

Notes: Estimates are marginal effects from linear probability models. Standard errors clustered at the job-advertisement level are in parentheses. The full sample of 9,396 observations is used for each regression model and the full set of control variables from eq. [1] is included. The details on how the estimates presented are produced are provided in online Appendix A2.3. 
than their white counterparts. The estimates shown in Table 6 indicate that the black-white differentials detected in Table 3 are not driven by greater discrimination against blacks with current unemployment spells. None of the estimates are statistically significant at any reasonable level, nor is it likely that the estimated differentials would be considered economically important. ${ }^{21}$

The next set of sensitivity checks examines whether racial discrimination varies with labor-market conditions. Because of the historically high rates of unemployment in each city studied during our sample period, the labor-market conditions present in each city would likely be considered "slack" or "loose." However, there is variation in the levels of unemployment in these cities in which résumés were submitted. The cities with relatively lower unemployment rates include Boston, Dallas, and Minneapolis, which had unemployment rates ranging from $5 \%$ to $6 \%$. The cities with relatively higher unemployment rates include Baltimore and Los Angeles, which had unemployment rates over $10 \%$. Atlanta and Portland had unemployment rates in between these two extremes, which were about $7 \%$. In our analysis, we consider Boston, Dallas, and Minneapolis as cities with relatively "tight" labor-market conditions, and Baltimore and Los Angeles are treated as having relatively "loose" labor-market conditions. The interview rate in cities with "tight" conditions is about $16 \%$, while it is over $19 \%$ in cities with "loose" conditions.

Table 7 presents the estimates for the black-white interview differential in cities with relatively tight labor-market conditions (column 1), the black-white interview differential in cities with relatively loose labor-market conditions

Table 7: Racial discrimination and labor-market conditions.

\begin{tabular}{llcr}
\hline $\begin{array}{c}\text { Tight labor } \\
\text { markets (1) }\end{array}$ & $\begin{array}{r}\text { Loose labor } \\
\text { markets (2) }\end{array}$ & $\begin{array}{r}\text { Loose labor markets relative } \\
\text { to tight labor markets (3) }\end{array}$ \\
\hline Black & $-0.031^{\star \star \star}$ & $-0.022^{\star}$ & 0.009 \\
& $(0.009)$ & $(0.013)$ & $(0.016)$ \\
\hline
\end{tabular}

Notes: Estimates are marginal effects from linear probability models. Standard errors clustered at the job-opening level are in parentheses. * and *** indicates statistical significance at the $10 \%$ and $1 \%$ levels, respectively. The full sample of 9,396 observations is used for each regression model and the full set of control variables from eq. [1] is included. The details on how the estimates presented are produced are provided in online Appendix A2.4.

21 It is also possible for the black and white job seekers to be randomly assigned a work-history gap immediately after completing their degrees. We examined whether "front-end" gaps in work history are responsible for the racial gap in interview requests, but we find no evidence that "front-end" gaps in work history explain the estimates presented in Table 3. 
(column 2), and the relative black-white differential between cities with loose and tight labor-market conditions. From Table 7, black applicants have interview rates that are 3.1 (column 1) and 2.2 (column 2) percentage points lower than their white counterparts in tight and loose labor markets, respectively. The test for whether these two differences are statistically different from one another indicates that the black-white differential in the relatively loose labor markets is not statistically different from that in the relatively tight labor markets (column 3).

\subsection{Empirical tests for different types of discrimination}

In general, there are two economic models of discrimination: the taste-based model (Becker 1971) and models of statistical discrimination (Aigner and Cain 1977; Arrow 1973; Cornell and Welch 1996; Lundberg and Startz 1983; Phelps 1972). ${ }^{22}$ The key difference between these different models is that the taste-based model emphasizes animosity as the source of differential treatment by race, and models of statistical discrimination are based on incomplete information. Becker's (1971) model predicts that racist employers would interview fewer black applicants than white applicants, despite both having the same productivity characteristics. ${ }^{23}$ Models of statistical discrimination can be separated into three classes: (i) those that emphasize differences in the means of unobservables between blacks and whites; ${ }^{24}$ (ii) those that emphasize differences in the

22 Another theory of discrimination is implicit discrimination, which originated in the field of psychology. It is a form of discrimination that can be taste based or statistical, but the differential treatment by race occurs unconsciously rather than consciously (Bertrand, Chugh, and Mullainathan 2005). In our context, implicit discrimination occurs when employers choose to interview otherwise identical white and black applicants at different rates without being aware that they are treating the two applicants differently on the basis of race. Such a situation might occur if employers make quick decisions concerning which job applicants to interview. Our data are not well-suited to determine whether discrimination occurs consciously or unconsciously. Implicit discrimination is difficult to investigate empirically, but Price and Wolfers (2010) and Rooth (2010) are notable exceptions. Implicit Association Tests (IATs) have been used, as in Rooth (2010), to measure racial prejudice, but van Ravenzwaaij, van der Maas, and Wagenmakers (2011) contest the reliability of IATs as a means to detect racial prejudice.

23 The discussion concerning Becker's (1971) theory is not exhaustive, as there are many aspects of Becker's model that we are unable to examine (e.g., market power, competition). See Charles and Guryan (2008) for an examination of other predictions made by Becker (1971). 24 Recall that correspondence studies are generally thought to circumvent the identification issues associated with mean differences in unobservables between blacks and whites (see Neumark 2012). 
variances of unobservables between blacks and whites; and (iii) those that emphasize risk aversion on the part of employers. While there are no definitive tests to isolate the type of discrimination observed, we rely on two approaches to help sort out the competing explanations for the observed patterns in the data: race-credential interactions (Bertrand and Mullainathan 2004; Lahey 2008) and the decomposition of racial discrimination into "level" and "variance" components (Neumark 2012).

The first set of empirical tests uses the following regression equation to examine how race interacts with different productivity/match-quality indicators:

$$
\begin{aligned}
\text { interview }_{i m c f j}= & \beta_{0}+\beta_{1} \text { black }_{i}+\beta_{2} \operatorname{signal}_{i}+\beta_{3} \text { black }_{i} \times \operatorname{signal}_{i}+\gamma \mathbf{X}_{i} \\
& +\phi_{m}+\phi_{c}+\phi_{f}+\phi_{j}+u_{i c m f j}
\end{aligned}
$$

The subscripts $i, m, c, f$, and $j$ and the variables black, $\mathbf{X}, \phi_{m}, \phi_{c}, \phi_{f}, \phi_{j}$, and $u$ are defined in eq. [1]. The variable signal is an indicator variable equal to one when an applicant is assigned a résumé attribute which indicates high expected productivity and/or a high degree of match quality between the applicant and the job opening. The parameter $\beta_{1}$ gives the average difference in the interview rate between black and white applicants with no signal assigned to them; the parameter combination $\beta_{1}+\beta_{3}$ gives the average difference in the interview rate between black and white applicants with a signal assigned to them; and the parameter $\beta_{3}$ indicates whether the racial gap in employment opportunities is smaller, larger, or similar between applicants with and without a signal assigned to them. We use three different signals for expected productivity and/or match quality when estimating eq. [2]: business degrees, internship experience, and infield work experience. Each of these résumé attributes has a positive effect on the interview rate, but internship and in-field work experience have much larger effects than business degrees. ${ }^{25}$

Table 8 presents the estimates for $\beta_{1}, \beta_{1}+\beta_{3}$, and $\beta_{3}$ from eq. [2]. Three sets of estimates are presented, which differ based on the expected-productivity/ match-quality signal being used. Panel A presents the estimates for the racial

25 In two companion papers (Nunley et al. 2014a, 2014b), we compare the interview rates of job seekers with business and non-business majors, job seekers with and without internship experience, and job seekers who became adequately employed (i.e., in-field work experience) and underemployed after graduation. Business degrees and internship experience improve employment prospects. However, the estimated differential between business and non-business majors is not statistically different from zero. By contrast, job seekers with internship experience have interview/callback rates that are $14 \%$ higher than those who did not obtain internship experience. Relative to in-field employment, spells of underemployment reduce the interview/ callback rates by about $30 \%$. 
Table 8: Race, productivity signals, and job opportunities.

\begin{tabular}{llll}
\hline & $\begin{array}{r}\text { No productivity } \\
\text { signal (1) }\end{array}$ & $\begin{array}{r}\text { Productivity } \\
\text { signal (2) }\end{array}$ & $\begin{array}{r}\text { Productivity signal relative to } \\
\text { no productivity signal (3) }\end{array}$ \\
\hline $\begin{array}{l}\text { Panel A: business degrees } \\
\text { Black }\end{array}$ & -0.010 & $-0.031^{\star \star \star}$ & $-0.021^{\star}$ \\
& $(0.009)$ & $(0.008)$ & $(0.012)$ \\
Panel B: internships & & & $-0.024^{\star}$ \\
Black & $-0.016^{\star \star}$ & $-0.040^{\star \star \star}$ & $(0.015)$ \\
Panel C: in-field experience & $(0.008)$ & $(0.013)$ & $-0.027^{\star \star}$ \\
Black & -0.008 & $-0.035^{\star \star \star}$ & $(0.013)$ \\
\hline
\end{tabular}

Notes: Estimates are marginal effects from linear probability models. Standard errors clustered at the job-advertisement level are in parentheses. * ${ }^{\star \star}$, and $* \star \star$ indicate statistical significance at the $10 \%, 5 \%$ and $1 \%$ levels, respectively. The estimates shown, which are based on eq. [2], in each panel are based on separate regression models. In particular, eq. [2] is estimated with different productivity and/or match-quality signals, including business degrees, internship experience, and in-field work experience. The full sample of 9,396 observations is used for each regression model and the full set of control variables from eq. [1] is included. Panel $A$ presents the estimated racial differences for business and non-business degree holders; Panel B presents the estimated racial differences for applicants with and without internship experience; and Panel $C$ presents the estimated racial differences for applicants with in-field and outof-field work experience.

gap in employment opportunities for non-business majors. We consider accounting, economics, finance, management, and marketing as business degrees, while psychology, biology, history, and English are considered non-business degrees. ${ }^{26}$ For non-business majors, black applicants have a one percentage point lower interview rate than white applicants (column 1). The analogous

26 It is likely that employers in the job categories in which we apply consider economics a business-related degree. However, we also included economics in the "non-business degree" category as a robustness check due to a nontrivial portion of economics departments being housed outside of business schools. With this reclassification, the results are slightly different. In particular, when economics is included in the non-business degree category, we find a negative and statistically significant differential between black and white applicants with non-business degrees. We continue to find an economically and statistically significant racial differential for applicants with business degrees. However, the difference-in-differences estimator, i.e., $\beta_{3}$, is not statistically different from zero, but the estimate is potentially significant in an economic sense because the estimated differential is over two percentage points. While the estimates differ somewhat, the overall message is the same: the extent of racial discrimination is greater in the business degree category than in the non-business degree category. 
differential is over twice as large for business majors (column 2). The racial gap in interview rates is two percentage points larger for business majors than for non-business majors (column 3). The estimate presented in column (1) is not statistically significant at conventional levels; column (2) is statistically significant at the 1\% level; and column (3), which tests whether the racial gap in employment opportunities for business majors differs from that for non-business majors, is statistically significant at the $10 \%$ level. $^{27}$

Panel B presents the estimates for the racial gap in employment opportunities for applicants with and without internship experience. In our case, internship experience is a type of in-field work experience, as the applicants were assigned an internship within the job category for which they are applying. ${ }^{28}$ Internship experience is working as a(n) "Equity Capital Markets Intern" in banking; "Financial Analyst Intern" in finance; "Insurance Intern" in insurance; "Project Management Intern" or "Management Intern" in management; "Marketing Business Analyst" in marketing; and "Sales Intern" or "Sales Future Leader Intern" in sales. For applicants without internship experience, black applicants have a 1.6 percentage point lower interview rate than white applicants (column 1). The analogous differential is more than twice as large for applicants with internship experience (column 2). The larger racial gap detected for applicants with internship experience is economically larger than the analogous estimated differential for applicants without internship experience. In particular, the racial gap in interview rates for applicants with internship experience is 2.4 percentage points larger than that for applicants without internship experience (column 3). The estimates presented in columns (1), (2), and (3) are statistically significant at the 5\%,1\% and 10\% levels, respectively.

Panel $\mathrm{C}$ presents the estimates for the racial gap in employment opportunities for applicants with and without in-field work experience. In-field work experience varies by the job category: it is working as a "Bank Branch Assistant Manager" in banking; "Accounts Payable" or "Financial Advisor" in finance; "Insurance Sales Agent" in insurance; "Distribution Assistant Manager" or “Administrative Assistant” in management; "Marketing Specialist” in marketing;

27 We estimated an alternative specification that grouped the degrees into the following categories: business, social sciences, sciences, and humanities. These estimates are presented in Online Appendix Table A2. Ultimately, our findings with respect to the interaction between race and business degrees are corroborated by this alternative specification: the extent of racial discrimination is economically and statistically more important in the business degree category than the other degree categories.

28 The internship experience was acquired in Summer 2009, the year before the applicants completed their college degrees in May 2010. The internships lasted only for 3 months. The online appendix provides more details on the internships randomly assigned to applicants. 
and "Sales Representative" or "Sales Consultant" in sales. Out-of-field experience is employment at well-known retail stores with either a "Retail Associate" or "Sales Associate" job title. ${ }^{29}$ The "out-of-field" experience that is randomly assigned to applicants is effectively a form of "underemployment," as a college degree would not be required for these types of jobs. For applicants with out-offield experience, we find no statistical evidence of a differential in the interview rates between black and white applicants (column 1). However, we find economically and statistically significant interview differentials between black and white applicants with in-field work experience. In particular, the interview rate for black applicants with in-field work experience is 3.5 percentage points lower than that for white applicants with in-field work experience (column 2). In addition, the estimated difference in the interview rate between black and white applicants with in-field work experience is larger than the analogous differential for applicants with out-of-field experience, and it is statistically significant at conventional levels (column 3). ${ }^{30}$

In Table 9, we examine the racial gap in employment opportunities between job seekers with none, some, or all of the three aforementioned productivity signals. In particular, column (1) presents the estimated differential between black and white job applicants with non-business degrees, no internship experience, and out-of-field work experience; column (2) presents the estimated interview differential between black and white applicants with business degrees (also presented in column (2) of Table 8); column (3) presents the estimated interview differential between black and white applicants with business degrees and internship experience; and column (4) shows the estimated interview differential between black and white applicants with business degrees, internship experience, and in-field work experience. ${ }^{31}$ We find no evidence of a racial gap in employment opportunities for applicants with non-business degrees, no internship experience, and out-of-field work experience (column 1). However, black applicants have a

29 For the sales job category, we exclusively use "Retail Associate" as the relevant type of outof-field experience.

30 Because the random assignment of gaps in work history created random variation in experience levels, we examine whether race interacts with the amount of experience in general, out-offield work experience, and in-field work experience. This specification and the results from it are discussed in Online Appendix A3.1, and the estimates are presented in Online Appendix Table A3. Overall, we find that racial gap in interview rates declines with the amount of work experience. However, these findings mask some interesting patterns in the data: the effects of work experience on the racial gap in interview rates differ markedly based on the type of work experience. For outof-field experience, the racial gap in interview rates declines with work experience, but the racial gap in interview rates increases with the amount of in-field work experience.

31 Online Appendix A2.5 provides details on how the estimates in Table 9 are generated. 
Table 9: Racial gap in job opportunities with none, some, or all productivity signals.

\begin{tabular}{lrccc}
\hline & (1) & (2) & (3) & (4) \\
\hline Black & 0.008 & $-0.031^{\star \star \star}$ & $-0.052^{\star \star \star}$ & $-0.067^{\star \star \star}$ \\
& $(0.014)$ & $(0.008)$ & $(0.017)$ & $(0.024)$ \\
Productivity signals & & & & \\
Business degree & No & Yes & Yes & Yes \\
Internship experience & No & No & Yes & Yes \\
In-field experience & No & No & No & Yes \\
Observations in cells & 1,610 & 1,941 & 643 & 671 \\
\hline
\end{tabular}

Notes: Estimates are marginal effects from linear probability models. Standard errors clustered at the job-opening level are in parentheses. ${ }^{\star \star \star}$ indicates statistical significance at the $1 \%$ level. The full sample of 9,396 observations is used for each regression model and the full set of control variables from eq. [1] is included. The estimated black-white differentials are based on the computation of linear combinations of parameters. The details on how the estimates presented are produced are provided in online Appendix A2.5.

$19 \%$ lower interview rate than white applicants when both have business degrees (column 2). The racial gap in employment opportunities is larger when job seekers have business degrees and internship experience (column 3). In particular, black applicants have a 31\% lower interview rate than their white counterparts. When applicants have business degrees, internship experience, and in-field work experience, black applicants have an interview rate that is $33 \%$ lower than that for otherwise identical white applicants (column 4). ${ }^{32}$

Our final attempt to shed light on the channel through which discrimination operates is the methodology developed by Neumark (2012). ${ }^{33}$ Using a

32 It may appear that black applicants are worse off (in terms of job opportunities) when they acquire business degrees, internship experience, and in-field work experience, but this is not the case. In fact, the discrimination against black job seekers is worse when white applicants have these credentials and black applicants do not. However, when black applicants have these credentials and white applicants do not, there is generally no statistically significant difference in interview rates between black and white job seekers. The estimates that generate these conclusions are discussed in Online Appendix A2.3 and presented in Online Appendix Tables A4 and A5.

33 A requirement of Neumark's decomposition is the incorporation of multiple productivityrelated characteristics into the experimental design. We randomize characteristics displayed on the applicants' résumés that affect interview rates (e.g., in-field and internship experience). The incorporation of such characteristics can be used to obtain an estimate for the ratio of standard deviations of unobservables, which allows one to test whether they are statistically different from one another between groups (e.g., blacks versus whites). We find that the effects of the observable characteristics are not statistically different for black and white applicants, which is necessary for identification in Neumark's proposed methodology. 
heteroskedastic probit model that allows the variance of unobservables to depend on race, we decompose the marginal effect of race into two components: an effect that operates through the "level" and an effect that operates through the "variance." The level component measures taste-based discrimination, while the variance component measures statistical discrimination. We find that the partial effect, which is the sum of the level and variance components, is $-0.025,{ }^{34}$ which is consistent with what we find via the linear probability models presented in Table 3. The marginal effect through the level is -0.038 and the marginal effect through the variance is 0.013. The marginal effect through the level and the marginal effect through the variance are not statistically significant at conventional levels. ${ }^{35}$ However, we emphasize the size of the estimate for the level component relative to the baseline estimate from Table $3(-0.038$ versus -0.022). The larger marginal effect through the level suggests that the baseline estimate tends to understate the extent of taste-based discrimination. These findings suggest that the structural parameter, i.e., the level component, is indeed negative and economically large, which could be interpreted as evidence of tastebased discrimination.

Ewens, Tomlin, and Wang (2014; ETW henceforth) posit a number of hypotheses that allow one to test for taste-based discrimination, which are able to test, albeit imperfectly, with our data. Their model predicts that the racial gap widens (narrows) as positive (negative) information is added - relative to a "no-information" baseline - to their fictitious applicant's answer to rental-housing advertisements. While our data do not contain the "no-information" base case, which is an advantage of ETW's reliance on rental-housing markets over résumé audits of the labor market, we observe an increase in the interview gap between black- and white-named applicants as positive attributes are added to their résumés. Furthermore, there is no difference between whiteand black-named applicants who exhibit the lowest level of qualifications in our study - a non-business degree, no internship experience, and out-of-field work experience. These patterns in the data are consistent with Hypotheses $2 \mathrm{~A}$ and $3 \mathrm{~A}$ (see Section 2), which buttresses an argument favoring taste-based discrimination as the explanation for our findings. Moreover, the decomposition approach

34 We were unable to estimate the full model depicted in eq. [1]. In particular, it was not possible to estimate eq. [1] via the heteroskedastic probit model with the job-advertisement dummy variables $\left(\phi_{j}\right)$ included. However, we were able to estimate the heteroskedastic probit model with all of the other controls included (i.e., $\mathbf{X}, \phi_{m}, \phi_{c}$, and $\phi_{f}$ ).

35 The marginal effect that operates through the level is very close to being statistically significant at the $10 \%$ level ( $p$-value $=0.12$ ), while the marginal effect that operates through the variance is nowhere near statistically significant $(p$-value $=0.63)$. 
developed by Neumark (2012), which is designed to separate out taste-based discrimination and variance-based statistical discrimination, suggests our baseline model tends to understate the extent of taste-based discrimination.

Despite the empirical evidence pointing toward discrimination based on tastes, we are unable to rule out risk aversion on the part of employers as a possible explanation. Given that we applied to higher-skill jobs (i.e., those that require a college degree), it is likely that employers would expect to invest in the human capital of their new hires. Furthermore, there is uncertainty regarding applicant quality. If the signal-to-noise ratio is lower for blacks than it is for whites, employers would interview relatively fewer black applicants because of their aversion to risk, which could explain the larger racial gap at the "highskill” level. The lower signal-to-noise ratio for blacks could result from the discounting of attributes possessed by blacks (relative to whites) because the employers have less experience interacting with blacks. It is difficult, perhaps impossible, for us to test for this type of discrimination, as we have no way of knowing the extent of interaction an employer has had with a particular group.

\subsection{Discrimination in jobs with customer interaction}

Becker (1971) contends that discrimination in hiring need not operate through employer preferences. Instead, discrimination can also occur via customer and/ or employee discrimination. In this subsection, we examine whether the differential treatment by race is robust for jobs that require significant customer interaction. ${ }^{36}$ While our data do not provide a clean test of customer discrimination, the submission of applications to many different types of jobs provides an indirect way of examining the possibility that discrimination could occur

36 We focus on jobs that require customer interaction, as it is relatively straightforward to identify such jobs. It is difficult, however, to examine employee discrimination using our data. The problem with categorizing jobs that require substantial interaction among colleagues is that such jobs tend to require a higher degree of skill or relevant experience as well. For example, job titles that include the words "Manager," "Director," "Supervisor," "Administration," "Coordinator," "Operations," and "Leader" require interaction among colleagues, but these jobs also likely require specific skill sets or training. However, it is important to point out that we only applied to jobs for which our applicants were qualified to get. In fact, many of our applicants have, for example, managerial experience, as a portion of them became employed in such jobs after completing their degrees in May 2010. In Online Appendix Table A6, we use the words "Manager," "Director," "Supervisor," "Administration," "Coordinator," "Operations," and "Leader" to classify jobs as requiring significant interaction among coworkers. We find that the estimated black-white differentials are small and not statistically different from zero in these types of jobs. 
because of an employer's beliefs about its customer base. Our approach is similar to that of Holzer and Ihlanfeldt (1998), who consider evidence of greater discrimination in jobs that require contact with customers, such as sales and service occupations, as evidence of customer discrimination.

In our case, we compare the employment opportunities facing black and white applicants for jobs that require contact with customers. To classify the job openings, we use the information conveyed in the job titles as a way to classify customer-focused and "other" jobs. In particular, we treat job titles that include the words "Customer," "Sales," “Advisor," "Representative," “Agent," and "Loan Officer" as jobs that require interaction with the firm's customers.

We estimate the following regression model:

$$
\begin{aligned}
\text { interview }_{i m c f j}= & \beta_{0}+\beta_{1} \text { black }_{i}+\beta_{2} \text { customer }_{j}+\beta_{3} \text { black }_{i} \times \text { customer }_{j} \\
& +\gamma \mathbf{X}_{i}+\phi_{m}+\phi_{c}+\phi_{f}+\phi_{j}+u_{i c m f j}
\end{aligned}
$$

The subscripts $i, m, c, f$, and $j$ and the variables black, $\mathbf{X}, \phi_{m}, \phi_{c}, \phi_{f}, \phi_{j}$, and $u$ are defined in eq. [1]. The variable customer is a zero-one indicator that equals one when the job requires interaction between the applicant and the firm's customers and zero otherwise. We are interested in $\beta_{1}+\beta_{3}$, which gives the average difference in the interview rate between black and white applicants who applied to jobs that require interaction with customers. ${ }^{37}$ The estimate for $\beta_{3}$ is informative as well, as it tests whether the estimated black-white differential in customer-related jobs is statistically different from the estimated black-white differential in other jobs.

The estimates for the linear combination $\beta_{1}+\beta_{3}$ are presented in Table 10 . The columns in Table 10 differ based on the words in the job titles that are used to create the customer variable. The words in the job titles used to classify jobs as being customer focused are listed below the estimates in Table 10. In column (1), we begin with job titles that have a high likelihood of having significant customer and employee interaction. In columns (2)-(5), we successively add jobs that are also likely to have significant customer interaction. The purpose of successively adding job titles to the customer categorizations stems from the

37 In Online Appendix Table A7, we examine whether there is differential treatment between men and women in jobs that require interaction with customers. These estimates are presented in Online Appendix Table A7. The regression model used to produce these estimates is analogous to eq. [3], except black is replaced with female. We find no statistical evidence that men and women are treated differently in customer-focused jobs. In Online Appendix Table A7, we also present estimates for male-female differences for jobs that require interaction among coworkers, finding no differences between men and women in these types of jobs. Footnote 36 provides information on how the jobs that require coworker interaction are classified. 
Table 10: Racial discrimination in jobs with customer interaction.

\begin{tabular}{lccccc}
\hline & (1) & (2) & (3) & (4) & (5) \\
\hline Black & $-0.036^{\star \star \star}$ & $-0.038^{\star \star \star}$ & $-0.042^{\star \star \star}$ & $-0.041^{\star \star \star}$ & $-0.044^{\star \star \star}$ \\
& $(0.013)$ & $(0.014)$ & $(0.013)$ & $(0.013)$ & $(0.013)$ \\
Words in job title: & & & & & \\
Customer & Yes & Yes & Yes & Yes & Yes \\
Sales & Yes & Yes & Yes & Yes & Yes \\
Advisor & No & Yes & Yes & Yes & Yes \\
Representative & No & No & Yes & Yes & Yes \\
Agent & No & No & No & Yes & Yes \\
Loan officer & No & No & No & No & Yes \\
Observations in cells & 2,701 & 2,797 & 3,128 & 3,255 & 3,377 \\
\hline
\end{tabular}

Notes: Estimates are marginal effects from linear probability models. Standard errors clustered at the job-advertisement level are in parentheses. ${ }^{\star * *}$ indicates statistical significance at the $1 \%$ level. The full sample of 9,396 observations is used for each regression model and the full set of control variables from eq. [1] is included. The estimates presented above are based on eq. [3].

need to gauge the sensitivity of the estimates to broader definitions of the customer identifier. The estimates presented in Table 10 indicate that the racial discrimination detected in previous specifications operates primarily through a higher degree of discrimination in jobs that require customer interaction, which is consistent with recent work by Laouénan (2013). ${ }^{38}$ In addition, the estimate for $\beta_{3}$ from eq. [3] (not presented in Table 10) is positive, large, and highly statistically significant, an indication that the racial discrimination in customerfocused jobs is economically and statistically larger than that in "other" jobs. While inconclusive, these findings could indicate that employers attempt to appease their customer base, which may have racial preferences, by interviewing fewer blacks relative to whites. ${ }^{39}$

38 Using U.S. data, Laouénan (2014) estimates that the decline in racial prejudice has led to a reduction in the racial wage gap, but that the rise in jobs that require customer interaction explains the persistence of the racial wage gap. Using French data, Combes et al. (2013) test for labor-market discrimination against African immigrants, finding evidence of both ethnic and customer discrimination.

39 As a way to further investigate whether discrimination operates through a customer channel, we examine whether there is more/less discrimination in jobs that require customer interaction in cities with relatively lower and relatively higher shares of blacks in the population. For customer-related jobs, we find an even larger black-white interview differential in cities where blacks comprise a relatively smaller share of the population (Los Angeles and 


\section{Conclusions}

We present experimental evidence from a correspondence test of racial discrimination in the labor market for recent college graduates. The correspondence framework, which incorporates a detailed set of randomly assigned productivity characteristics for a large number of résumés from white- and black-named job candidates, provides a powerful method to detect racial discrimination among the college-educated. The analysis of survey data is unlikely to yield convincing evidence of discrimination among the college educated because of selection bias. The coarseness of the education variables (e.g., highest grade completed, school quality, and school inputs) and other productivity characteristics contained in prominent employment data series could also mask important premarket factors that predict differences in the skill distributions between black and white college graduates.

Our results indicate that black-named applicants are approximately $14 \%$ less likely than white-named applicants to receive interview requests. We find strong evidence that the racial gap in employment opportunities widens with perceived productivity characteristics. In addition, the differential treatment by race detected appears to operate primarily through greater discrimination in jobs that require significant customer interaction, as we find much larger blackwhite interview differentials (about 28\%) when applying to such jobs. We demonstrate that the estimated black-white differentials in interview rates are unlikely to be driven by the uniqueness of the racially identifying names, socioeconomic status, gaps in work history, labor-market conditions, or greater racial discrimination against women. While it is difficult to determine the precise channel through which discrimination operates, our data tend to support tastebased discrimination, but we are unable to rule our risk aversion on the part of employers as a possible explanation.

Acknowledgments: We thank the Office of Research and Sponsored Programs at the University of Wisconsin - La Crosse and the Economics Department at Auburn University for generous funding. We also thank Taggert Brooks, Mary

Portland) than in cities where blacks comprise a relatively larger share of the total population (Atlanta and Baltimore). The black-white interview differentials in customer-related jobs in cities with a relatively smaller share of blacks in the population is 4.9 percentage points, while the analogous estimate is 2.7 percentage points in cities with a relatively larger share of blacks in the population. It is important to point out, however, that using the share of blacks in the city population has its limitations as a proxy for the racial make-up of a firm's customer base, as firms may sell their output locally, regionally, nationally, or internationally. 
Hamman, Joanna Lahey, William Lincoln, James Murray, Mark Owens, Artie Zillante, and seminar participants at the 2013 Southern Economic Association and 2014 Society of Labor Economists annual meetings for helpful comments; David Neumark for sharing his programs; and Samuel Hammer, James Hammond, Lisa Hughes, Amy Lee, Jacob Moore, and Yao Xia for excellent research assistance.

\section{References}

Abel, J. R., R. Deitz, and Y. Su. 2014. "Are Recent College Graduates Finding Good Jobs?” Federal Reserve Bank of New York: Current Issues in Economics and Finance 20(1):1-8.

Ahmed, A. M., and M. Hammarstedt. 2008. "Discrimination in the Rental Housing Market: A Field Experiment on the Internet." Journal of Urban Economics 64(2):362-72.

Aigner, D. J., and G. Cain. 1977. "Statistical Theories of Discrimination in Labor Markets." Industrial and Labor Relations Review 30(2):175-87.

Altonji, J. G., and R. M. Blank. 1999. "Race and Gender in the Labor Market." In Handbook of Labor Economics, edited by O. Ashenfelter and D. Card, Vol. 3, 3243-59. Elsevier.

Anderson, L. R., R. G. Fryer Jr, and C. A. Holt. 2006. "Discrimination: Evidence from Psychology and Economics Experiments." In Handbook on Economics of Racial Discrimination, edited by W. Rogers, 97-115. Northampton: Edward Elgar Publishing.

Arrow, K. J. 1973. "The Theory of Discrimination." In Discrimination in Labor Markets, edited by A. Orley and A. Rees, 3-33. Princeton, NJ: Princeton University Press.

Ayres, I., and P. Siegelman. 1995. "Race and Gender Discrimination in Bargaining for a New Car." American Economic Review 85(3):304-21.

Baert, S., B. Cockx, N. Gheyle, and C. Vandamme. (2013). "Do Employers Discriminate Less if Vacancies are Difficult to Fill? Evidence from a Field Experiment." IZA Discussion Paper Series No. 7145 (2013 January).

Ball, S. B., C. Eckel, P. J. Grossman, and W. Zane. 2001. "Status in Markets." Quarterly Journal of Economics 116(1):161-88.

Becker, G. S. 1971. The Economics of Discrimination. 2nd ed. Chicago, IL: University of Chicago Press.

Bertrand, M., and S. Mullainathan. 2004. "Are Emily and Greg More Employable Than Lakisha and Jamal? A Field Experiment on Labor Market Discrimination." American Economic Review 94(4):991-1013.

Bertrand, M., D. Chugh, and S. Mullainathan. 2005. "Implicit Discrimination." American Economic Review: Papers and Proceedings 95(2):94-8.

Bosch, M. M., A. Carnero, and L. Farre. 2010. "Information and Discrimination in the Rental Housing Market: Evidence from a Field Experiment.” Regional Science and Urban Economics 40(1):11-19.

Booth, A. L., A. Leigh, and E. Varganova. 2012. "Does Ethnic Discrimination Vary Across Minority Groups? Evidence from a Field Experiment." Oxford Bulletin of Economics and Statistics 74(4):547-73. 
Carlsson, M., and D.-O. Rooth. 2007. "Evidence of Ethnic Discrimination in the Swedish Labor Market Using Experimental Data." Labour Economics 14(4):716-29.

Charles, K. K., and J. Guryan. 2008. "Prejudice and Wages: An Empirical Assessment of Becker's the Economics of Discrimination." Journal of Political Economy 116(5):773-809.

Charles, K. K., and J. Guryan. 2011. "Studying Discrimination: Fundamental Challenges and Recent Progress." NBER Working Paper Series No. 17156.

Combes, P.-P., B. Decreuse, M. Laouénan, and A. Trannoy. 2013. "Customer Discrimination and Employment Outcomes: Theory and Evidence from the French Labor Market." Journal of Labor Economics 34(1).

Cornell, B., and I. Welch. 1996. "Culture, Information, and Screening Discrimination." Journal of Political Economy 104(3):542-71.

Doleac, J. L., and L. C. D. Stein. 2013. "The Visible Hand: Race and Online Market Outcomes." Economic Journal 123(572):F469-92.

Eriksson, S., and D.-O. Rooth. 2014. "Do Employers Use Unemployment as Sorting Criterion When Hiring? Evidence from a Field Experiment." American Economic Review 104(3):1014-39.

Ewens, M., B. Tomlin, and L. C. Wang. 2014. "Statistical Discrimination or Prejudice: A Large Sample Field Experiment." Review of Economics and Statistics 96(1):119-34.

Fershtman, C., and U. Gneezy. 2001. "Discrimination in a Segmented Society: An Experimental Approach.” Quarterly Journal of Economics 161(1):351-77.

Fryer, R. G., D. Pager, and J. L. Spenkuch. 2011. "Racial Disparities in Job Finding and Offered Wages." Journal of Law and Economics 56(3):633-89.

Glaeser, E., D. I. Laibson, J. A. Scheinkman, and C. L. Soutter. 2000. “Measuring Trust.” Quarterly Journal of Economics 115(3):811-46.

Heckman, J. J. 1998. “Detecting Discrimination." Journal of Economic Perspectives 12(2):101-16. Heckman, J. J., and P. Siegelman. 1993. "The Urban Institute Audit Studies: Their Methods and Findings." In Clear and Convincing Evidence: Measurement of Discrimination in America, edited by M. Fix and R. Struyk, 187-258. Washington, DC: Urban Institute.

Holzer, H. J., and K. R. Ihlanfeldt. 1998. "Customer Discrimination and Employment Outcomes for Minority Workers." Quarterly Journal of Economics 113(3):835-67.

Hoynes, H., D. L. Miller, and J. Schaller. 2012. "Who Suffers During Recessions?” The Journal of Economic Perspectives 26(3):27-47.

Kroft, K., F. Lange, and M. J. Notowidigdo. 2013. "Duration Dependence and Labor Market Conditions: Theory and Evidence from a Field Experiment." Quarterly Journal of Economics 128(3):1123-67.

Lahey, J. 2008. “Age, Women and Hiring: An Experimental Study." Journal of Human Resources 43(1):30-56.

Lahey, J., and R. A. Beasley. 2009. “Computerizing Audit Studies.” Journal of Economic Behavior and Organization 70(3):508-14.

Laouénan, M. 2013. "Hate at First Sight': Evidence of Consumer Discrimination Against African Americans in the U.S." Institut de Recherches Economiques et Sociales de I'Université catholique de Louvain Discussion Paper 2013-32.

Laouénan, M. 2014. “Can’t Get Enough': Prejudice, Contact Jobs and the Racial Wage Gap in the U.S.” IZA Discussion Paper No. 8006.

Levitt, S. D., and J. A. List. 2007. "What Do Laboratory Experiments Measuring Social Preferences Reveal About the Real World?." Journal of Economic Perspectives 21(2):153-74. 
List, J. A. 2004. "The Nature and Extent of Discrimination in the Marketplace: Evidence from the Field." Quarterly Journal of Economics 119(1):49-89.

Lundberg, S. J., and R. Startz. 1983. "Private Discrimination and Social Intervention in Competitive Labor Market." American Economic Review 73(3):340-7.

Neumark, D. 1996. "Sex Discrimination in Hiring in the Restaurant Industry: An Audit Study." Quarterly Journal of Economics 111(3):915-41.

Neumark, D. 2012. "Detecting Discrimination in Audit and Correspondence Studies." Journal of Human Resources 47(4):1128-57.

Nunley, J. M., M. F. Owens, and R. Stephen Howard. 2011. "The Effects of Information and Competition on Racial Discrimination: Evidence from a Field Experiment." Journal of Economic Behavior and Organization 80(3):670-9.

Nunley, J. M., A. Pugh, N. Romero, and R. Alan Seals. 2014a. "Unemployment, Underemployment, and Employment Opportunities: Results from a Correspondence Audit of the Labor Market for College Graduates." Auburn University Department of Economics Working Paper Series No. 2014-04.

Nunley, J. M., A. Pugh, N. Romero, and R. Alan Seals 2014b. "College Major, Internship Experience, and Employment Opportunities: Estimates from a Résumé Audit.” Auburn University Department of Economics Working Paper Series No. 2014-03.

Oreopoulos, P. 2011. "Why Do Skilled Immigrants Struggle in the Labor Market? A Field Experiment with Thirteen Thousand Résumés." American Economic Journal: Economic Policy 3(4):148-71.

Phelps, E. S. 1972. "The Statistical Theory of Racism and Sexism." American Economic Review 62(4):659-61.

Price, J., and J. Wolfers. 2010. "Racial Discrimination among NBA Referees." Quarterly Journal of Economics 125(4):1859-87.

Rampell, C. 2013. "With Positions to Fill, Employers Wait for Perfection." New York Times, March 6. http://www.nytimes.com/2013/03/07/business/economy/despite-job-vacanciesemployers-shy-away-from-hiring.html?pagewanted=all_r $r=0$

Riach, P. A., and J. Rich. 2002. "Field Experiments of Discrimination in the Market Place." Economic Journal 112(483):F480-F518.

Rooth, D.-O. 2010. “Automatic Associations and Discrimination in Hiring: Real World Evidence." Labour Economics 17(3):523-34.

Spreen, T. L. 2013. "Recent College Graduates in the U.S. Labor Force: Data from the Current Population Survey." Monthly Labor Review, February: 3-13.

van Ravenzwaaij, D., H. L. J. van der Maas, and E.-J. Wagenmakers. 2011. "Does the Name-Race Implicit Associate Test Measure Racial Prejudice?” Experimental Psychology 58(4):271-7.

Yinger, J. 1986. "Measuring Racial Discrimination with Fair Housing Audits: Caught in the Act." American Economic Review 76(5):881-93.

Supplemental Material: The online version of this article (DOI: 10.1515/bejeap-2014-0082) offers supplementary material, available to authorized users. 